\title{
Method of transfection affects the cAMP-mediated induction of the RII $\beta$ subunit of protein kinase A in Sertoli cells: inhibition of response by increase in intracellullar calcium
}

\author{
Line M Grønning, Helle K Knutsen, Winnie Eskild ${ }^{1}$, Vidar Hansson, Kjetil Taskén and Kristin A Taskén \\ Institute of Medical Biochemistry, University of Oslo, N-0317 Oslo, Norway and ${ }^{1}$ Institute of Biochemistry, University of Oslo, \\ N-0316 Oslo, Norway \\ (Correspondence should be addressed to L M Gronning, Institute of Medical Biochemistry, University of Oslo, P.O. Box 1112 Blindern, \\ N-0317 Oslo, Norway)
}

\begin{abstract}
mRNA for the regulatory subunit RII $\beta$ of cAMP-dependent protein kinase is stimulated more than 50 -fold by cAMP in primary cultures of rat Sertoli cells. We have previously shown that this induction involves regulation of transcriptional activation as well as mRNA stabilization. The rat RII $\beta$ gene contains no cAMP response element (CRE), and the induction of RII $\beta$ mRNA is slow and requires on-going protein synthesis. When a construct containing the $5^{\prime}$-flanking region of the RII $\beta$ gene upstream of a CAT reporter was transfected into Sertoli cells by the calcium phosphate method, low and variable responses to cAMP (three- to fivefold) were observed, whereas a 15- to 20-fold increase in reporter activity by cAMP was observed after lipofectamine transfection. Interestingly, when a vector containing CRE elements upstream of a reporter gene was transfected into Sertoli cells, the responses to cAMP were similar regardless of the transfection method used. We have also demonstrated that increased intracellular levels of calcium by A23187 and thapsigargin dramatically inhibit cAMPmediated induction of RII $\beta$ mRNA, but not the mRNA for the CRE-containing RI $\alpha$ gene. Furthermore, decreased cAMP responsiveness of endogenous RII $\beta$ mRNA (but not RI $\alpha$ ) was also observed in calcium phosphate-transfected Sertoli cells but not in lipofectamine-transfected cells. Thus, calcium-mediated reduction in cAMP response appears to be a gene-specific phenomenon.
\end{abstract}

European Journal of Endocrinology 141 75-82

\section{Introduction}

Follicle-stimulating hormone (FSH) regulates spermatogenesis through the cAMP-signalling pathway in Sertoli cells. The overall response to FSH is complex, involving secretion of numerous products and regulation of a number of metabolic, structural and enzymatic activities (1). Whereas short-term effects of FSH are directly due to protein kinase A (PKA)-dependent phosphorylation, more long-term effects involve the regulation of gene expression. Best characterized of sequence-specific elements regulating transcriptional activity of genes in response to cAMP is the cAMPresponsive element, CRE (TGACGTCA), binding members of the CREB/CREM (CRE-binding protein and CRE modulator) family of transcription factors (2). Besides acting through the cAMP-signalling pathway, FSH may influence intracellular levels of $\mathrm{Ca}^{2+}(3,4)$. The $\mathrm{Ca}^{2+}$ level in Sertoli cells is regulated by adenosine through $\mathrm{P}_{2}$-purinergic receptors, endothelin-1, insulin-like growth factor-I, and several other hormones (5-8).
Furthermore, hydrolysis of phosphoinosides and $\mathrm{Ca}^{2+}$ changes in Sertoli cells are also regulated by the neighbouring germ cells (9), suggesting that germ cells may be responsible for modulating Sertoli cell response to $\mathrm{FSH}$ in vivo.

Treatment of Sertoli cells with FSH is associated with the appearance of a new regulatory subunit, $\mathrm{RII} \beta$, of PKA which makes up $10 \%$ of total cAMP binding in stimulated cells (10). The increase in $\operatorname{RII} \beta$ protein follows a dramatic increase in RII $\beta$ mRNA. The kinetics of the induction of RII $\beta$ mRNA by cAMP is relatively slow (maximum 6-16 h), dependent on on-going protein synthesis and is reported to involve transcriptional activation as well as mRNA stabilization in Sertoli cells (11). In Friend's erythroleukemic cells a similar increase in RII $\beta$ mRNA in response to cAMP is seen, and this is reported to be primarily due to posttranscriptional modification (12). The rat $\mathrm{RII} \beta$ gene lacks a consensus CRE element, but two possible cAMPresponsive regions have been identified in granulosa and Sertoli cells $(13,14)$. In contrast to RII $\beta$, cAMP-mediated 
induction of RI $\alpha$ is independent of protein synthesis and one concensus CRE element is present in the human RI $\alpha$ gene (15). Contrary to the 50 -fold induction of RII $\beta$ mRNA by cAMP in untransfected cells, CAT constructs containing the RII $\beta 5^{\prime}$-flanking region conferred only a three- to fivefold stimulation of CAT activity by cAMP after calcium phosphate transfection (14). For that reason, we wanted to investigate whether cAMP responsiveness of the RII $\beta$ gene was affected by the transfection method itself.

\section{Materials and methods}

\section{Plasmid constructs}

The basal promoter and cAMP-responsive region of the rat RII $\beta 5^{\prime}$-flanking region $(-723$ to -123$)$ in front of a CAT reporter gene (pCATbasic; Promega, Madison, WI, USA) in forward (RII $\beta$ CAT) and reverse (revRII $\beta$ CAT) orientation (14) were used for transfections. Furthermore, a plasmid (4xCREtkLuc) containing four copies of a CRE element derived from the human chorionic gonadotrophin (hCG) promoter in front of the herpes simplex thymidine kinase minimal promoter $(-81$ to +52 ) fused to the firefly luciferase reporter gene (pT81) was employed $(16,17)$. The vectors pT81 and 4xCREtkLuc were kind gifts from Professor Johan Lund, University of Bergen, Norway. The vectors pCATControl (Promega E1011) and pGL3Control (Promega E1741) were used as internal controls in transfection experiments.

\section{Preparation of Sertoli and peritubular cell cultures}

Primary cultures of rat Sertoli cells and peritubular cells were made from testes of 19-day-old Sprague-Dawley rats (Møllegaards Breeding Centre Ltd, Copenhagen, Denmark) according to the method of Dorrington et al. (18) with some modifications. The cells were plated in six-well plates $(35 \mathrm{~mm} /$ well $)$ for transfections or in $10 \mathrm{~cm}$ culture dishes (Nunc, Copenhagen, Denmark) for Northern analysis and cultured in modified Eagles' minimal essential medium (MEM; 212090-022, GIBCO BRL, Grand Island, NY, USA) containing streptomycin $(100 \mathrm{mg} / \mathrm{l})$, penicillin $\left(10^{5} \mathrm{IU} / \mathrm{l}\right)$, fungizone $(0.25 \mathrm{mg} / \mathrm{l})$, L-glutamine $(2 \mathrm{mmol} / \mathrm{l})$ and fetal calf serum $(10 \%$; GIBCO BRL, 11099-117) at $32{ }^{\circ} \mathrm{C}$ in a humidified atmosphere with $5 \% \mathrm{CO}_{2}$. After 3 days, the cells were incubated further in serum-free modified MEM.

\section{Treatment of Sertoli cell cultures}

Cell cultures were stimulated with 8-CPTcAMP $(100 \mu \mathrm{mol} / \mathrm{l})\left(\mathrm{C}-3912\right.$, Sigma, St Louis, MO, USA), $\mathrm{Ca}^{2+}$ ionophore A23187 $(0.5 \mu \mathrm{mol} / \mathrm{l})$ (Sigma, C-5149) or thapsigargin $(10 \mu \mathrm{mol} / \mathrm{l})$ (Sigma, T-9033) alone or in combination for the times indicated in the Figure legends.
A23187 and thapsigargin were solubilized in DMSO, and controls received corresponding concentrations of DMSO (0.2\%o and $1.0 \%$ respectively). Prior to and during experiments, medium was changed every $12 \mathrm{~h}$.

\section{Transfections, CAT and luciferase assays}

Transient transfections were carried out 5 days after plating. Transfection by calcium phosphate precipitation was performed by the method of Graham \& Van der Eb (19) with some modifications. Two hours before transfection the medium was changed from serum-free modified MEM to modified Dulbecco's modified Eagles' medium (DMEM; GIBCO BRL, 074-2100 OP) containing $2 \mathrm{mmol} / \mathrm{l}$ L-glutamine, $0.15 \% \mathrm{NaHCO}_{3}$ and antibiotics and $10 \%$ fetal calf serum $(2.5 \mathrm{ml}$ per well $)$. Plasmids $(9.0 \mu \mathrm{g}$ reporter vector and $3.0 \mu \mathrm{g}$ internal control plasmid) were mixed with $825 \mu \mathrm{l} 0.25 \mathrm{~mol} / \mathrm{l}$ $\mathrm{CaCl}_{2}$. An equal volume of a solution containing $42 \mathrm{mmol} / \mathrm{l} \mathrm{HEPES}, 274 \mathrm{mmol} / \mathrm{l} \mathrm{NaCl}, 9.9 \mathrm{mmol} / \mathrm{l} \mathrm{KCl}$, $1.8 \mathrm{mmol} / \mathrm{l} \mathrm{Na}_{2} \mathrm{HPO}_{4}$ and $11 \mathrm{mmol} / \mathrm{l}$ dextrose, $\mathrm{pH} 7.05$, to which had previously been added $0.1 \times \mathrm{PBS}$ $(10 \times$ PBS: $\quad 1.37 \mathrm{~mol} / \mathrm{l} \quad \mathrm{NaCl}, \quad 26.8 \mathrm{mmol} / \mathrm{l} \mathrm{KCl}, 46$ $\mathrm{mmol} / \mathrm{l} \mathrm{Na}_{2} \mathrm{HPO}_{4}, 14.7 \mathrm{mmol} / \mathrm{l} \mathrm{KH}_{2} \mathrm{PO}_{4}$ ) was mixed with the DNA/ $\mathrm{CaCl}_{2}$ solution while vortexing in order to generate appropriately sized calcium phosphate particles. The mixture was immediately added dropwise $(275 \mu \mathrm{l} /$ well $)$ to the cells giving a final DNA concentration of $2 \mu \mathrm{g}$ per well. After $6 \mathrm{~h}$, cells were washed twice with modified DMEM without serum and incubated further.

Lipofectamine-mediated transfection was performed essentially as recommended by the manufacturer (GIBCO BRL). DNA $(9.0 \mu \mathrm{g}$ reporter plasmid and $3.0 \mu \mathrm{g}$ internal control vector) was mixed with $570 \mu \mathrm{l}$ modified MEM without antibiotics. Lipofectamine (30 $\mu \mathrm{l}$; GIBCO BRL) was then added, vortexed and incubated for $15 \mathrm{~min}$ at room temperature. In the meantime, cells were washed once in modified MEM without antibiotics. After $15 \mathrm{~min}, 5.4 \mathrm{ml}$ modified MEM without antibiotics was added to the DNA/lipofectamine mixture, and the medium in each well was replaced by $1 \mathrm{ml}$ of the DNA/lipofectamine solution giving a final concentration of $2 \mu \mathrm{g}$ DNA per well. Three hours later, media were changed to modified MEM (containing antibiotics).

Twenty hours after transfection, cells were stimulated with 8 -CPTcAMP $(100 \mu \mathrm{mol} / \mathrm{l})$. After $28 \mathrm{~h}$ of stimulation, cells were harvested in reporter lysis buffer (Promega, E397A). CAT activities were measured according to the organic phase extraction method with some modifications (20). Luciferase activities were measured using luciferase assay reagent (Promega, E3971) and an LKB Wallac 1251 luminometer. CAT and luciferase activities were normalized for expression from internal control plasmids (the luciferase-encoding plasmid pGL3Control and the CAT-encoding plasmid pCATcontrol respectively). 


\section{RNA extraction and Northern analysis}

Total RNA from Sertoli cells was extracted by the guanidine isothiocyanate/ $\mathrm{CsCl}$ method as previously described (21). Northern analysis was performed using $20 \mu \mathrm{g}$ total RNA denatured in 50\% (v/v) formamide and $6 \%(\mathrm{v} / \mathrm{v})$ formaldehyde and subjected to electrophoresis in a $1.5 \%(\mathrm{w} / \mathrm{v})$ agarose gel containing $6.7 \%$ formaldehyde (22). Ethidium bromide staining of the gel verified equal loading in each lane. Complementary DNA probes for rat $\operatorname{RII} \beta(1.5 \mathrm{~kb})(23)$ and human $\mathrm{RI} \alpha(0.8 \mathrm{~kb})(24)$ were labelled with $\left[\alpha_{-}{ }^{32} \mathrm{P}\right] \mathrm{dCTP}$ using the megaprime DNA labelling system (RPN 1607, Amersham, Arlington Heights, IL, USA). Hybridization was performed with $50 \%$ formamide at $42{ }^{\circ} \mathrm{C}$ according to the ICN procedure. After hybridization, the filters were washed four times in a solution containing $2 \times$ standard saline citrate $(\mathrm{SSC} ; 300 \mathrm{mmol} / \mathrm{l} \mathrm{NaCl}$ and $30 \mathrm{mmol} / \mathrm{l}$ sodium citrate, $\mathrm{pH} 7.0$ ) with $0.1 \%$ SDS at $25^{\circ} \mathrm{C}$ for $5 \mathrm{~min}$ and twice in $0.1 \times$ SSC with $0.1 \%$ SDS at $50^{\circ} \mathrm{C}$ for $30 \mathrm{~min}$. The signal intensities of suitably exposed films (Amersham Hyperfilm MP) were estimated by the use of a densitometer (OmniMedia Scanner; XRS, 6cx, software; Bioimage; Ann Arbor, MI, USA).

\section{Results}

Figure 1 shows the morphology of primary cultures of untransfected Sertoli cells (Fig. 1A), Sertoli cells in culture transfected by the calcium phosphate method (Fig. 1B), and Sertoli cells transfected with lipofectamine (Fig. 1C). As seen from this figure, calcium phosphate transfection had a dramatic effect on cell morphology, whereas cells transfected with lipofectamine were almost unchanged.

We have previously shown that CAT constructs containing the RII $\beta 5^{\prime}$-flanking region conferred only a three- to fivefold cAMP induction of CAT activity in calcium phosphate-transfected Sertoli cells. We therefore examined whether lipofectamine-mediated transfection could enhance the cAMP response directed by the RII $\beta$ 5'-flanking region (Fig. 2A). In calcium phosphate-transfected cells, basal expression of pCATbasic increased by inserting the RII $\beta$ promoter and $5^{\prime}$ flanking region (RII $\beta$ CAT) upstream of the CAT gene. Furthermore, RII $\beta$ CAT conferred a threefold induction of CAT activity by cAMP (100 $\mu \mathrm{mol} / \mathrm{l} 8$-CPTcAMP). The basal and cAMP-stimulated levels of CAT expression directed by the RII $\beta$ promoter and $5^{\prime}$-flanking region when inserted in the reverse orientation (revRII $\beta$ CAT) were low and comparable with pCATbasic. Surprisingly, the RII $\beta$ promoter directed a 16-fold cAMP induction of CAT activity in lipofectamine-transfected Sertoli cells. This indicates that the calcium phosphate transfection method itself interferes with the cAMP pathway. In order to examine whether this is a general effect on cAMPregulated genes in Sertoli cells, we also transfected a CRE-containing construct by calcium phosphate and
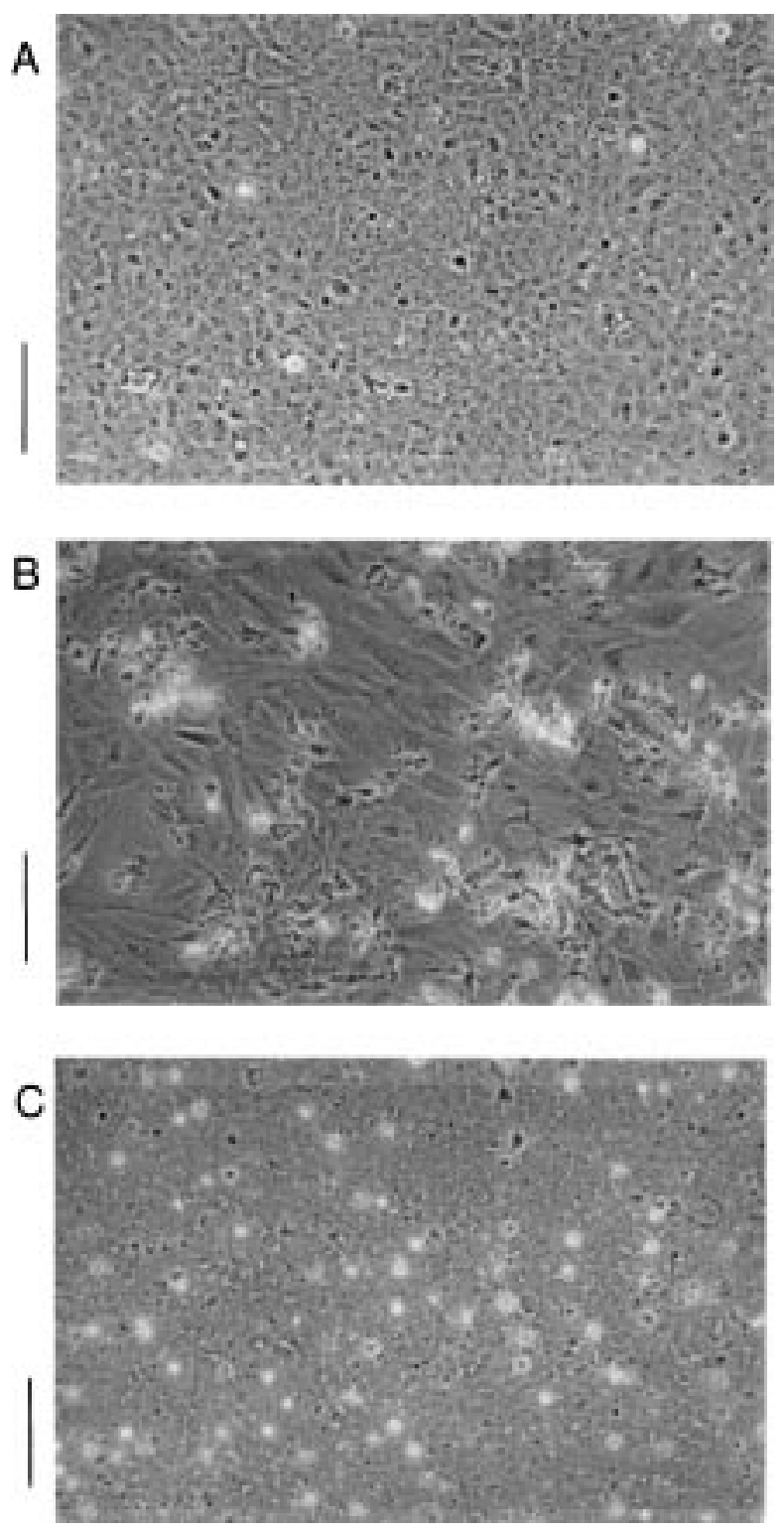

Figure 1 Morphology of transfected Sertoli cells. Sertoli cells were left untreated $(A)$ or transfected by the calcium phosphate $(B)$ or lipofectamine $(\mathrm{C})$ methods, and photographed in a Nikon inverted microscope. (Vertical line $=100 \mu \mathrm{m}$.).

lipofectamine transfection (Fig. 2B). The transfected plasmid 4xCREtkLuc contains four copies of a CRE derived from the hCG promoter upstream of the minimal promoter of the herpes simplex thymidine kinase gene. The enhancer-less vector pT81 showed low levels of luciferase expression in untreated and cAMP-stimulated Sertoli cells transfected by either method. Luciferase activity directed from 4 xCREtkLuc was induced sevento eightfold by cAMP regardless of transfection method used. Thus, blunted cAMP response after calcium phosphate transfection was not observed with the poly CRE construct. 
A
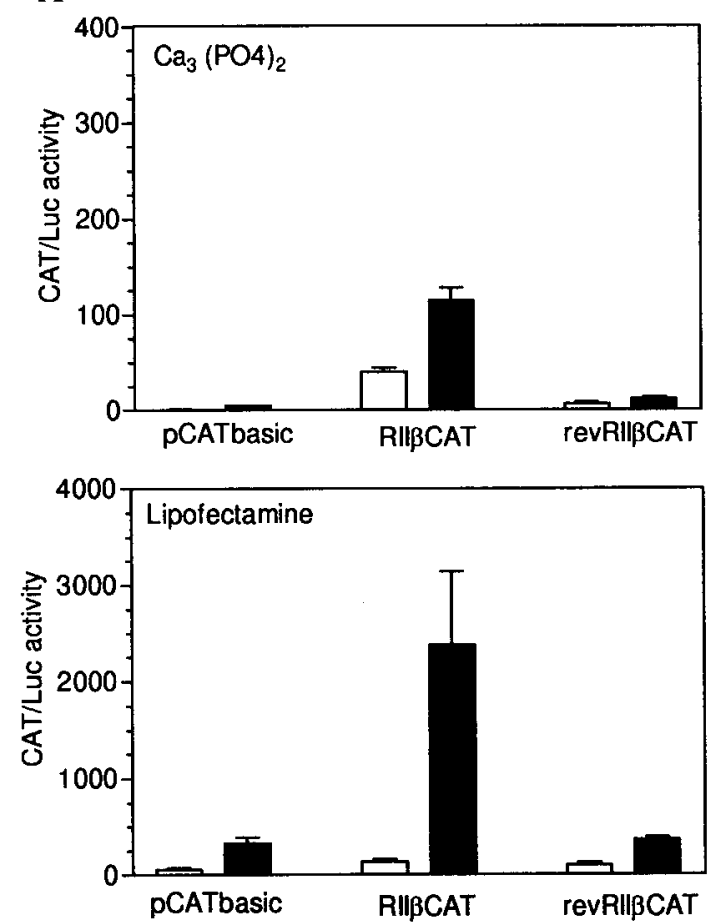

B
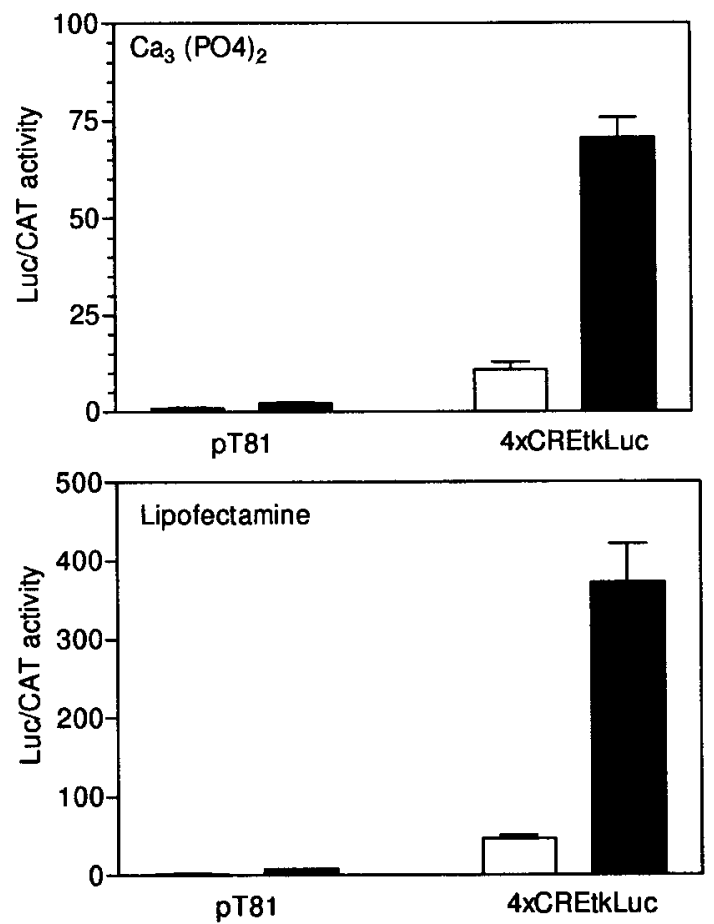

Figure 2 Basal and cAMP-stimulated reporter activities directed by the RII $\beta 5^{\prime}$-flanking region and a CRE-containing construct after calcium phosphate or lipofectamine transfection of Sertoli cells. Constructs containing the $5^{\prime}$-flanking region of the rat RII $\beta$ gene inserted in forward (RII $\beta C A T)$ or reverse (revRII $\beta C A T$ ) orientation in front of the CAT gene in pCATbasic as well as the empty vector (pCATbasic) (A) and a plasmid containing four CRE elements upstream of the thymidine kinase promoter coupled to the luciferase reporter gene (4xCREtkLuc) and the enhancer-less vector pT81 (B) were transfected by the calcium phosphate or lipofectamine methods. Twenty hours after transfection, the cells were either left untreated (open bars) or treated with 8-CPTcAMP $(100 \mu \mathrm{mol} / \mathrm{l})$ for $28 \mathrm{~h}$ (solid bars). Data represent luciferase (Luc) or CAT activities normalized for an internal CAT or Luc control plasmid respectively (means \pm S.E.M.; $n=3$ to 5 transfections in triplicate).

To further investigate the effect of $\mathrm{cAMP}$ on $\mathrm{RII} \beta$ promoter activity (RII $\beta$ CAT), increasing concentrations of 8-CPTcAMP were added to lipofectamine-transfected Sertoli cells. A concentration-dependent increase in CAT/luciferase activity by cAMP was observed (Fig. 3). Half-maximal induction was obtained with 20$30 \mu \mathrm{mol} / \mathrm{l}$ 8-CPTcAMP and maximal induction was obtained at approximately $100 \mu \mathrm{mol} / \mathrm{l}$ which is in agreement with that observed for other cAMP-regulated processes both in Sertoli cells as well as other cell systems $(25-27)$.

We have previously shown that the $\operatorname{RII} \beta$ gene is unresponsive to cAMP in primary cultures of peritubular cells transfected by the calcium phosphate protocol (14). Figure 4 shows basal and cAMP-stimulated CAT/ luciferase activities in liposome-transfected peritubular cells. RII $\beta$ CAT directed less than 1.5-fold induction of CAT/luciferase activity in the presence of $100 \mu \mathrm{mol} / \mathrm{l}$ 8-CPTcAMP.

Figure 5A shows the cAMP response of endogenous $\mathrm{RII} \beta$ mRNA in calcium phosphate- and lipofectaminetransfected Sertoli cells respectively. Densitometric scanning (upper panel) of suitably exposed autoradiograms

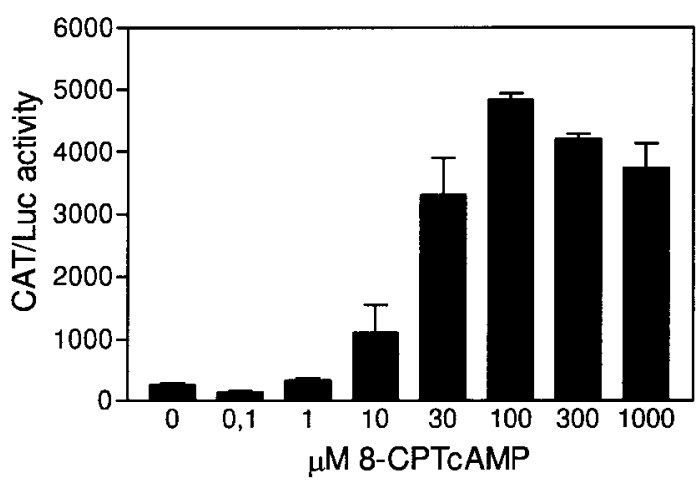

Figure 3 Concentration-dependent effects of cAMP on RII $\beta$ CAT activities in lipofectamine-transfected Sertoli cells. Sertoli cells were transfected with RII $\beta$ CAT by the lipofectamine method. Twenty hours after transfection, the cells were treated with increasing concentrations of 8 -CPTcAMP $(0.1-100 \mu \mathrm{mol} / \mathrm{l})$ for $28 \mathrm{~h}$. The data represent CAT activity normalized for luciferase activity directed by an internal control plasmid (means \pm S.E.M.; $n=3$ in parallel cell cultures). The experiment was repeated with similar results. 


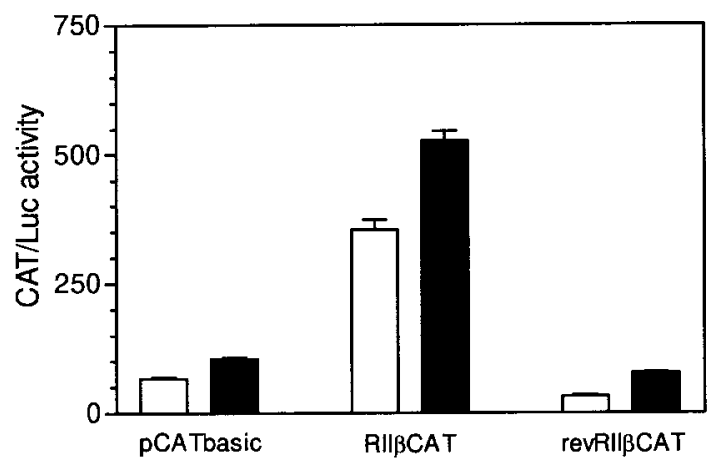

Figure 4 Basal and cAMP-stimulated CAT activities directed by the $5^{\prime}$-flanking region of the rat RII $\beta$ gene in lipofectamine-transfected peritubular cells. Primary cultures of peritubular cells were transfected by the lipofectamine method with the same CAT constructs as in Fig. 3. Twenty hours after transfection, cells were either left untreated (open bars) or treated with 8-CPTcAMP $(100 \mu \mathrm{mol} / \mathrm{l})$ for $28 \mathrm{~h}$ (solid bars). Data represent CAT activity normalized for luciferase (Luc) activity directed by an internal control plasmid (means \pm S.E.M.). The experiment was repeated twice with similar results.

(lower panel) from the Northern analyses showed that in cells transfected by the calcium phosphate method, the cAMP-mediated increase in RII $\beta$ mRNA level was reduced to $40 \%$ of that in untransfected cells (utransf., $100 \%$ ) in the presence of DNA (transf., RII $\beta$ CAT). Calcium phosphate transfection in the absence of DNA (mock-transf.) also resulted in a similar reduction in cAMP response of RII $\beta$ mRNA compared with untransfected cells. We then tested whether we could enhance the cAMP response of endogenous RII $\beta$ mRNA in Sertoli cells by using lipofectamine as the DNA carrier rather than calcium phosphate precipitation. After lipofectamine-mediated transfection, the cAMP response of endogenous RII $\beta$ mRNA was improved to $70 \%$ and $90 \%$ of the response in untransfected cells in the presence or absence of DNA respectively. The 20\% reduction in cAMP-stimulated RII $\beta$ levels observed after lipofectamine-mediated transfection of the RII $\beta$ construct may be due to competition for factors binding to endogenous and transfected RII $\beta$ promoters. In contrast to $\mathrm{RII} \beta$, the cAMP induction of $\mathrm{RI} \alpha$ mRNA was not affected by the choice of transfection protocol (Fig. 5B).

Due to the low cAMP response of RII $\beta$ in calcium phosphate-transfected Sertoli cells, we examined whether increased intracellular levels of calcium would affect the cAMP-mediated induction of endogenous RII $\beta$ or RI $\alpha$ mRNA (Fig. 6). The top panel of Fig. 6A shows densitometric scanning of autoradiograms of $\mathrm{RII} \beta$ mRNA shown below. cAMP treatment $(100 \mu \mathrm{mol} / \mathrm{l}$ 8 -CPTcAMP) for 5 and $10 \mathrm{~h}$ increased the RII $\beta$ mRNA level 30- and 50-fold above basal levels respectively. Interestingly, calcium ionophore A23187 (0.5 $\mu \mathrm{mol} / \mathrm{l})$ reduced the cAMP-mediated induction of $\mathrm{RII} \beta$ mRNA by $65 \%$ after $5 \mathrm{~h}$ and approximately $80 \%$ after $10 \mathrm{~h}$ of combined treatment with cAMP and A23187. The
Figure 5 Effects of transfection method on cAMP responsiveness of mRNA for rat RII $\beta$ and human $\mathrm{Rl} \alpha$. Primary cultures of Sertoli cells were transiently transfected by the calcium phosphate or the lipofectamine methods. Transfections were performed with RII $\beta$ CAT (transf) or without DNA (mock-transf) or left untransfected (untransf). Twenty hours after transfection, the cells were left untreated (basal (B)) or stimulated with CAMP $(100 \mu \mathrm{mol} / / \mathrm{l}$ 8-CPTCAMP (S)) for $12 \mathrm{~h}$. Total cellular RNA was extracted and analysed by the Northern technique using cDNA probes for rat RII $\beta(A)$ and human $\mathrm{Rl} \alpha(\mathrm{B})$. Densitometric scanning results are shown above the autoradiograms for RII $\beta$ mRNA in $(A)$ and presented relative to the level of CAMP-stimulated RII $\beta$ mRNA in untransfected cells, which is set to $100 \%$. The experiment was repeated twice with similar results.
A
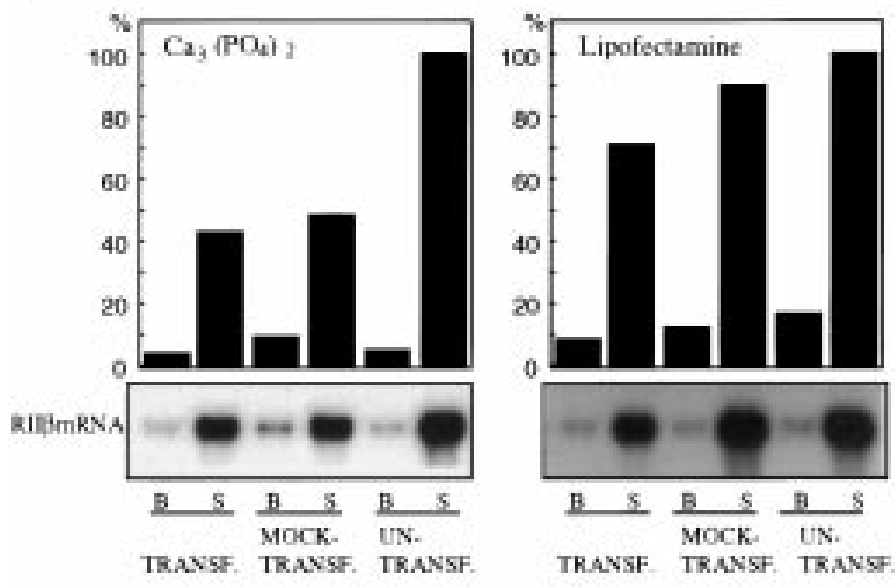

B
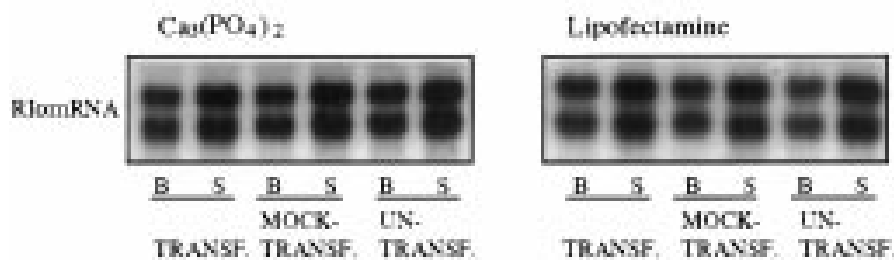
$\boldsymbol{A}$

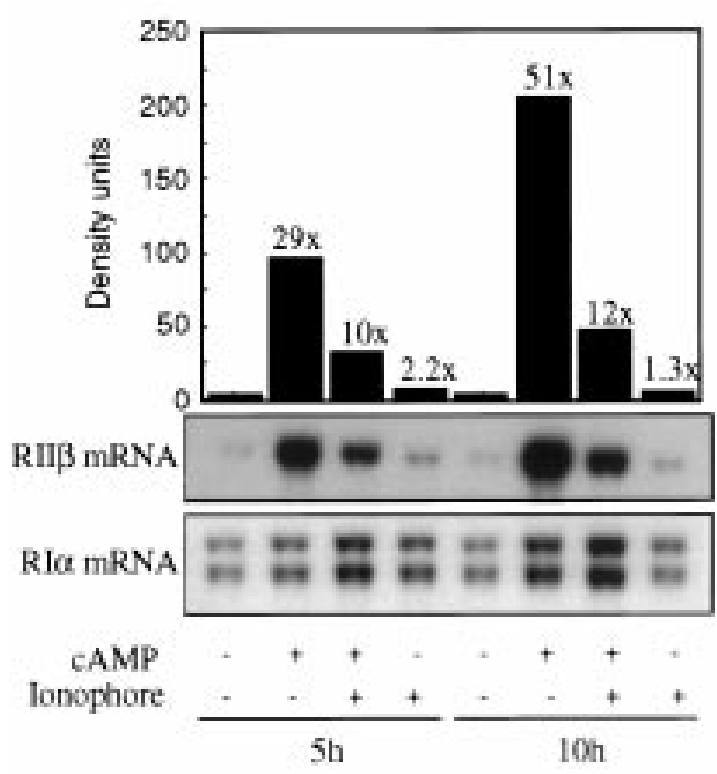

B

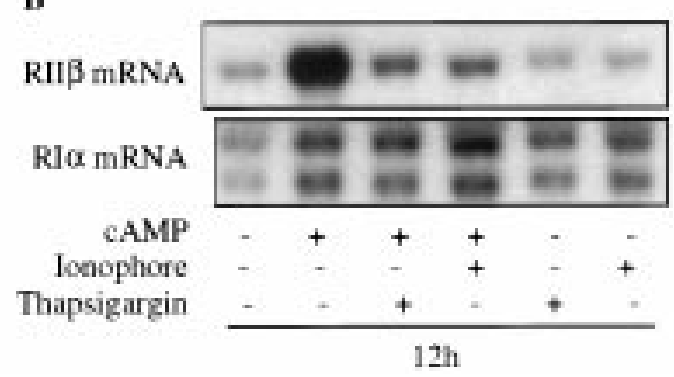

Figure 6 Effects of calcium ionophore and thapsigargin on cAMPinduction of mRNA for rat RII $\beta$ and human Rl $\alpha$ in Sertoli cells. After 2 days of culture in serum-free medium, primary cultures of rat Sertoli cells were incubated with calcium ionophore $(0.5 \mu \mathrm{mol} / \mathrm{l}$ A23187) for 5 to $12 \mathrm{~h}(\mathrm{~A}, \mathrm{~B})$ or thapsigargin $(10 \mu \mathrm{mol} / \mathrm{l})$ for $12 \mathrm{~h}(\mathrm{~B})$ in the absence or presence of cAMP $(100 \mu \mathrm{mol} / \mathrm{l} 8$-CPTcAMP). Total cellular RNA was extracted and analysed by the Northern technique using cDNA probes for rat $\mathrm{RII} \beta$ and human $\mathrm{Rl} \alpha$. Densitometric scanning results are shown above the autoradiogram for RII $\beta$ mRNA in (A). Fold induction relative to unstimulated cells is indicated on the top of each bar. The experiment was repeated three times with similar results.

calcium ionophore alone did not influence basal levels of RII $\beta$ mRNA. Furthermore, A23187 did not inhibit the cAMP-mediated increase in the RI $\alpha$ mRNA level (Fig. 6A). Similar results were obtained with another calcium ionophore, ionomycin $\left(5 \times 10^{-6} \mathrm{~mol} / \mathrm{l}\right)$ (data not shown). Since A23187 and ionomycin increase the intracellular concentration of calcium by transporting extracellular calcium across the cell membrane, we wanted to investigate whether secretion of calcium from intracellular stores would inhibit the cAMP pathway in a similar manner to that of A23187/ionomycin. Thapsigargin inhibits the $\mathrm{Ca}^{2+}$-ATPase of the endoplasmic reticulum resulting in increased secretion of calcium from the endoplasmic reticulum. Sertoli cells treated with thapsigargin $(10 \mu \mathrm{mol} / \mathrm{l})$ inhibited cAMPmediated increase in the RII $\beta$ mRNA level in the same way as calcium ionophore (Fig. 6B). In order to test whether the effect of calcium is at a post-transcriptional level, we prestimulated Sertoli cells with 8-CPTcAMP for $12 \mathrm{~h}$ to increase the level of RII $\beta$ mRNA, then cAMP was washed away and the cells incubated further with actinomycin D in the absence or presence of A23187. We did not observe any effect of calcium on RII $\beta$ mRNA decay (data not shown), indicating that the inhibitory effect of calcium occurs at the transcriptional level.

\section{Discussion}

The present study reports that calcium phosphate transfection and treatment with calcium ionophore or thapsigargin reduce the cAMP-mediated increase in the RII $\beta$ mRNA level in primary cultures of rat Sertoli cells. Lipofectamine-mediated transfection improved cAMP responsiveness of the RII $\beta$-gene fivefold compared with calcium phosphate transfection. Interestingly, the choice of transfection protocol did not affect cAMPmediated induction of a CRE-containing reporter construct .

Calcium is known to interact with the cAMPsignalling pathway at a number of levels (for references see 28-30). The antagonistic effect of $\mathrm{Ca}^{2+}$ on cAMPstimulated RII $\beta$ mRNA reflects interaction between the two signalling pathways on a factor(s) involved in signalling downstream of cAMP production. CREB may mediate both stimulatory and inhibitory effects of $\mathrm{Ca}^{2+}$ on cAMP-dependent transcriptional activation. CaM kinase IV has been shown to phosphorylate CREB at the same site (Ser 133) as PKA, whereas CaM kinase II in addition to phosphorylating Ser 133 also phosphorylates Ser 142 and thereby inhibits transcriptional activation by CREB $(28,31)$. The phosphorylation status of CREB is also dependent on the activity of protein phosphatase IIB which dephosphorylates Ser 133 (32). Thus, the relative level of activation of protein phosphatase IIB and CaM kinase II versus CaM kinase IV sets the mode of signalling through CREB. cAMP and $\mathrm{Ca}^{2+}$ synergistically induce the c-fos gene, a CREB/CREregulated gene in Sertoli cells (33). However, the cAMPmediated induction of the CRE-containing $\mathrm{RI} \alpha$ gene is not inhibited by $\mathrm{Ca}^{2+}$ as shown in this study. This observation make the mechanism of $\mathrm{Ca}^{2+}$ inhibition of cAMP at the level of CREB unlikely in case of RII $\beta$. However, it is still possible that $\mathrm{Ca}^{2+}$ upregulates a CREB/CRE-regulated early response gene which acts as a negative regulator of RII $\beta$ expression.

Surprisingly, treatment with calcium ionophore A23187 or thapsigargin of lipofectamine-transfected Sertoli cells did not affect cAMP-induced CAT activity conferred by the RII $\beta$ promoter (data not shown), although A23187 and thapsigargin inhibited cAMPmediated induction of endogenous RII $\beta$ mRNA in 
untransfected Sertoli cells (Fig. 6). The explanation for this could be that $\mathrm{Ca}^{2+}$ exerts its effect on $\mathrm{RII} \beta$ expression at a post-transcriptional level as shown for other genes and other cell types (34). However, our studies with actinomycin D do not support such a hypothesis (data not shown). Alternatively, the inhibitory effect of $\mathrm{Ca}^{2+}$ may require the presence of active protein kinase $\mathrm{C}$ (PKC.) We have previously shown that activation of PKC inhibits cAMP induction of RII $\beta$ mRNA and that this inhibition persists after PKC down-regulation (35). The lack of response to A23187 and thapsigargin in lipofectamine-transfected cells could be due to PKC inactivation after lipofectamine transfection as has been observed in other cell types (36). The loss of cAMP responsiveness of RII $\beta$ may also be related to the morphological changes observed. Means et al. (37) showed that FSH and $\mathrm{Ca}^{2+}$ differentially regulate the shape of Sertoli cells. Furthermore, we have preliminary data indicating increased secretion of autocrine factors after calcium phosphate transfection of Sertoli cells. Whether these factors interact with the cAMP-signalling pathway and contribute to the altered morphology of Sertoli cells is not known.

In contrast to RI $\alpha$ mRNA, cAMP-induced levels of endogenous RII $\beta$ mRNA were strongly reduced by addition of calcium ionophore or calcium phosphate transfection. Mock-transfection with lipofectamine did not affect cAMP stimulation of either mRNA. A 25\% reduction in cAMP-stimulated $\mathrm{RII} \beta$ mRNA levels after lipofectamine-mediated transfection of an RII $\beta$ CAT construct may be due to competition for factors binding to the endogenous and transfected RII $\beta$ promoters. The observation that calcium phosphate-mediated transfection of the RII $\beta$ CAT construct only conferred a threeto fivefold cAMP responsiveness may also be due to competition of low abundant transcription factors. However, titrations of DNA load with respect to cAMP responsiveness conferred to the CAT reporter indicated that this was not the case (data not shown).

By inducing a new regulatory subunit of PKA in Sertoli cells, cAMP probably enhances hormone sensitivity of the PKA holoenzyme involving RII $\beta$. Furthermore, expression of RII $\beta$ in Sertoli cells by FSH/cAMP may mediate cell-specific effects of cAMP/PKA through subcellular targeting. Specific anchoring of RII $\beta$ to AKAP75 in cortical-actin and plasma membranes has been shown to enhance cAMP-mediated regulation of CREB four- to tenfold in thyroid cells (38). Thus, the inhibitory effect of $\mathrm{Ca}^{2+}$ on cAMP-mediated induction of $\mathrm{RII} \beta$ may be a mechanism whereby $\mathrm{Ca}^{2+}$ desensitizes cAMP-mediated gene regulation in Sertoli cells.

\section{Acknowledgements}

The skilful technical assistance of Gladys Josefsen and Guri Opsahl is greatly appreciated. This work was supported by The Norwegian Research Council, The
Norwegian Cancer Society, Novo Nordisk Foundation Committee, and The Anders Jahre Foundation.

\section{References}

1 Griswold MD. Actions of FSH in mammalian Sertoli cells. In The Sertoli Cell, pp 493-508. Eds LD Russell \& MD Griswold. Clearwater: Cache River Press 1993.

2 Montminy M. Transcriptional regulation by cyclic AMP. Annual Review of Biochemistry 199766 807-822.

3 Gorczynska E \& Handelsman DJ. The role of calcium in folliclestimulating hormone signal transduction in Sertoli cells. Journal of Biological Chemistry 1991266 23739-23744.

4 Gorczynska E, Spaliviero J \& Handelsman DJ. The relationship between cyclic AMP and calcium in mediating follicle-stimulating hormone signal transduction in Sertoli cells. Endocrinology 1994 134 293-300.

5 Filippini A, Ricciolo A, Cesaris PD, Paniccia R, Teti A, Stefanini M et al. Activation of inositol phospholipid turnover and calcium signaling in rat Sertoli cells by P2-purinergic receptors: Modulation of follicle-stimulating hormone responses. Endocrinology $19941341537-1545$.

6 Sharma OP, Flores JA, Leong DA \& Veldhuis JD. Mechanisms by which endothelin-1 stimulates increased cytosolic free calcium ion concentration in single rat Sertoli cells. Endocrinology 1994 135 127-134.

7 Gorczynska E \& Handelsman DJ. Androgens rapidly increase the cytosolic calcium concentration in Sertoli cells. Endocrinology $19951362052-2059$.

8 Gorczynska E, Spaliviero J \& Handelsman DJ. Cyclic adenosine $3^{\prime}, 5^{\prime}$-monophosphate-independent regulation of cytosolic calcium in Sertoli cells. Endocrinology 1996137 2617-2625.

9 Welsh MJ \& Ireland ME. The second messenger pathway for germ cell-mediated stimulation of Sertoli cells. Biochemical and Biophysical Research Communications 1992184 217-224.

10 Landmark BF, Fauske B, Eskild W, Skålhegg B, Lohmann SM, Hansson $\mathrm{V}$ et al. Identification, characterization, and hormonal regulation of $3^{\prime}, 5^{\prime}$-cyclic adenosine monophosphate-dependent protein kinases in rat Sertoli cells. Endocrinology 1991129 2345-2354.

11 Taskén KA, Knutsen HK, Attramadal H, Taskén K, Jahnsen T, Hansson $\mathrm{V}$ et al. Different mechanisms are involved in cAMPmediated induction of mRNAs for subunits of cAMP-dependent protein kinases. Molecular Endocrinology 19915 21-28.

12 Gross RE, Lu XY \& Rubin CS. Regulation of the expression of the regulatory subunit of cAMP-dependent protein kinase II $\beta$ in Friend erythroleukemic cells. Evidence for posttranscriptional control and a central role for the $\mathrm{C}$ subunit. Journal of Biological Chemistry $19902658152-8158$.

13 Kurten RC, Levy LO, Shey J, Durica JM \& Richards JS. Identification and characterization of the GC-rich and cyclic adenosine $3^{\prime}, 5^{\prime}$-monophosphate (cAMP)-inducible promoter of the type II $\beta$ cAMP-dependent protein kinase regulatory subunit gene. Molecular Endocrinology 19926 536-550.

14 Knutsen HK, Taskén K, Eskild W, Richards JS, Kurten RC, Torjesen PA et al. Characterization of the $5^{\prime}$-flanking region of the gene for the cAMP-inducible protein kinase A subunit, RII $\beta$, in Sertoli cells. Molecular and Cellular Endocrinology $1997129101-$ 114.

15 Solberg R, Sandberg M, Natarajan V, Torjesen PA, Hansson V, Jahnsen $\mathrm{T} \&$ Tasken $\mathrm{K}$. The human gene for the regulatory subunit RI alpha of cyclic adenosine $3^{\prime}, 5^{\prime}$-monophosphatedependent protein kinase: two distinct promoters provide differential regulation of alternately spliced messenger ribonucleic acids. Endocrinology 1997138 169-181.

16 Nordeen SK. Luciferase reporter gene vectors for analysis of promoters and enhancers. BioTechniques 19886 454-457.

17 Bakke M \& Lund J. Mutually exclusive interactions of two nuclear orphan receptors determine activity of a cyclic 
$3^{\prime}, 5^{\prime}$-monophosphate-responsive sequence in the bovine CYP17 gene. Molecular Endocrinology 19959 327-339.

18 Dorrington JH, Roller NF \& Fritz IB. Effects of follicle-stimulating hormone on cultures of Sertoli cell preparations. Molecular and Cellular Endocrinology 19753 57-70.

19 Graham FL \& van der Eb AJ. A new technique for the assay of infectivity of human adenovirus S DNA. Virology 197352 456467.

20 Pothier F, Ouellet M, Julien JP \& Guérin SL. An improved CAT assay for promoter analysis in either transgenic mice or tissue culture cells. DNA and Cell Biology 199211 83-90.

21 Eskild W, Ree AH, Levy FO, Jahnsen T \& Hansson V. Cellular localization of mRNAs for retinoic acid receptor- $\alpha$, cellular retinol-binding protein, and cellular retinoic acid-binding protein in rat testis: evidence for germ cell-specific mRNAs. Biology of Reproduction 199144 53-61.

22 Chirgwin JM, Przybyla AE, MacDonald KJ \& Rutter WJ. Isolation of biologically active ribonucleic acid from sources enriched in ribonuclease. Biochemistry 197918 5294-5299.

23 Jahnsen T, Hedin L, Kidd VJ, Beattie WG, Lohmann SM, Walter U et al. Molecular cloning, cDNA structure and regulation of the regulatory subunit of type II cAMP-dependent protein kinase from rat ovarian granulosa cells. Journal of Biological Chemistry $198626112352-12361$.

24 Sandberg M, Taskén K, Øyen O, Hansson V \& Jahnsen T. Molecular cloning, cDNA structure and deduced amino acid sequence for a type I regulatory subunit of cAMP-dependent protein kinase from human testis. Biochemical and Biophysical Research Communications 1987149 939-945.

25 Taskén KA, Jacobs FW, Hansson V \& Haugen TB. The $\alpha$-subunit of mRNAs for $G_{s}$ and $G_{02}$ are differentially regulated by protein kinase $\mathrm{A}$ and protein kinase $\mathrm{C}$ in rat Sertoli cells. Biochimica et Biophysica Acta $19951260269-275$.

26 Skålhegg BS, Landmark BF, Døskeland SO, Hansson V, Lea T \& Jahnsen T. Cyclic AMP-dependent protein kinase type I mediates the inhibitory effects of $3^{\prime}, 5^{\prime}$-cyclic adenosine monophosphate on cell replication in human $\mathrm{T}$ lymphocytes. Journal of Biological Chemistry 1992267 15707-15714.

27 Torgersen KM, Vaage JT, Levy FO, Hansson V, Rolstad B \& Taskén K. Selective activation of cAMP-dependent protein kinase type inhibits rat Natural Killer cell cytotoxicity. Journal of Biological Chemistry 1997272 5495-5500.

28 Matthews RP, Guthrie CR, Wailes LM, Zhao X, Means AR \& McKnight GS. Calcium/calmodulin-dependent protein kinase types II and IV differentially regulate CREB-dependent gene expression. Molecular and Cellular Biology 199414 6107-6114.
29 Impey S, Wayman G, Wu Z \& Storm DR. Type I adenylyl cyclase functions as a coincidence detector for control of cyclic AMP response element-mediated transcription: synergistic regulation of transcription by $\mathrm{Ca}^{2+}$ and isoproterenol. Molecular and Cellular Biology $1994148272-8281$.

30 Liu F, Thompson MA, Wagner S, Greenberg ME \& Green MR. Activating transcription factor 1 can mediate $\mathrm{Ca}(2+)$ - and cAMPinducible transcriptional activation. Journal of Biological Chemistry $19932686714-6720$.

31 Sun P, Enslen H, Myung PS \& Maurer RA. Differential activation of CREB by $\mathrm{Ca}^{2+} /$ calmodulin-dependent protein kinases type II and type IV involves phosphorylation of a site that negatively regulates activity. Genes and Development 19948 2527-2539.

32 Schwaninger M, Blume R, Kruger M, Lux G, Oetjen E \& Knepel W. Involvement of the $\left(\mathrm{Ca}^{2+}\right)$-dependent phosphatase calcineurin in gene transcription that is stimulated by cAMP through cAMP response elements. Journal of Biological Chemistry 1995270 $8860-8866$

33 Jia M-C, Ravindranath N, Papadopoulos V \& Dym M. Regulation of $c$-fos mRNA expression in Sertoli cells by cyclic AMP, calcium, and protein kinase $\mathrm{C}$ mediated pathways. Molecular and Cellular Biochemistry $199615643-49$.

34 Ross J. mRNA stability in mammalian cells. Microbiological Reviews 199559 423-450.

35 Taskén KA, Knutsen HK, Eikvar L, Taskén K, Eskild W, Jahnsen T et al. Protein kinase C activation by 12-O-tetradecanoylphorbol 13-acetate modulates messenger ribonucleic acid levels of two of the regulatory subunits of $3^{\prime}, 5^{\prime}$-cyclic adenosine monophosphatedependent protein kinases $(\mathrm{RII} \beta$ and $\mathrm{RI} \alpha)$ via multiple and distinct mechanisms. Endocrinology 1992130 1271-1280.

36 Farhood H, Bottega R, Epand RM \& Huang L. Effect of cationic cholesterol derivatives on gene transfer and protein kinase $\mathrm{C}$ activity. Biochimica et Biophysica Acta 19921111 239-246.

37 Means AR, Tash JS, Chafouleas JG, Lagace L \& Guerrero V. Regulation of the cytoskeleton by $\mathrm{Ca}^{2+}$-calmodulin and cAMP. Annals of the New York Academy of Sciences 1982383 69-84.

38 Feliciello A, Giuliano P, Porcellini A, Garbi C, Obici S, Mele E et al. The $\mathrm{V}$-Ki-Ras oncogene alters cAMP nuclear signaling by regulating the location and the expression of cAMP-dependent protein kinase IIbeta. Journal of Biological Chemistry 1996271 25350-25359.

Received 16 November 1998

Accepted 11 March 1999 